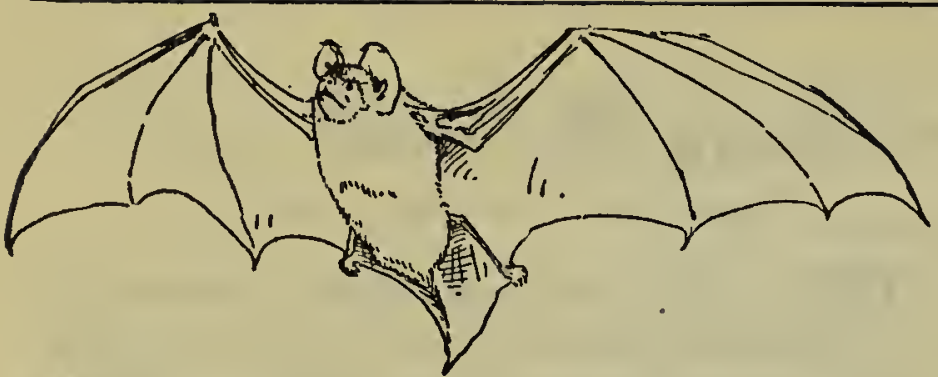

THE BAT, so unpredictapie, is observed in the most unusual places. I have seen him hanging head downward under the eaves of granaries. Once, during the time when the old grain binders were in use, on turning the cut grain up into the packers, up came a bat into the sheaf. Before it could be touched it soared away, high up into the sky. They can be seen in the dusk hovering around the intake airshaft of coal mines and will become drawn down the shaft by suction. Often have I placed my hand into one particular hole, when we were privileged to visit the workings below, and would always find two or three bats.

But when you are seated comfortably reading at home in the living room, and a bat suddenly makes its appearance and commences to give a demonstration of

\section{The Bat}

\author{
By Arthur Ward, Swift Current
}

its sensitiveness in approaching objects, there is need of some explanation.

Such was the case about 10 p.m on the night of June 5 . Where the bat came from is a mystery. It would fly under the furniture and around the room, then alight on the curtains and take off again until finally we opened the door and allowed it to go. We have not the slightest idea how the bat gained access to the house.

Radar equipped, the bat avoids obstacles with ease, using its tail membrane as a $\mathrm{n}$ undercarriage, curved to catch insects and carry its young. The Brown Bat, one of about two thousand species in the world, is as agile on the wing as most bircis and drinks water while it flies. Though it is not blind, it is more dependent on its ears than its eyes.

\section{A Fisher at Hazelcliffe}

Ey Mrs. Bert Ford

A BOUT the first of June a neighbour of ours who lives near the banks of the beautiful Qu'Appelle Valley, saw what he thought was a porcupine in an oak tree twelve feet from the ground. As porcupines in these areas are quite a menace to livestock, he snot the animal. On examination he discovered his error. On writing to the Provincial museum he was informed that the animal was a Fisher.

According to people who have lived here over sixty years, this is the first Fisher to have been seen in this district. It was sent to the museum where it was reported that if it had not escaped from a fisher ranch in northern Saskatchewan, it was from its native haunts. The animal is to be mounted by the museum.

\section{CARNIVOROUS PLANTS}

(Continued from page 13) stances. The leaf-margins are usually curled; this is increased after insects are trapped. Occasionally a leaf-margin may roll over far enough to cover up its victim. Laplanders are said to use the Butterwort leaves to curdle milk.

Three species of Bladderwort are found in the province, namely; Greater Bladderwort (Utricularia vulgaris), Flat-leaved Bladderwort (U. intermedia) and Lesser Bladderwort (U. minor). They are yellow flowered, rootless plants which live suspended in the water and are provided with bladders to entrap small animals and in addition, give the plant buoyancy. The bladders are always pale green, partially transparent and each is provided with a trap or valve which allows animals to enter but not to escape. The trapped animals are chiefly small shell-fish (crustaceans); but larvae of insects, worms, etc., are also imprisoned in the bladders. Death and digestion of the unfortunate creatures soon follows. 